Petra Georgala, M.A., Faculty of Law, Masaryk University, Czech Republic

Doc. JUDr. Ing. Michal Radvan, PhD, Faculty of Law, Masaryk University, Czech Republic

\title{
THE SYSTEM OF PUBLICATION OUTPUTS EVALUATION IN THE CZECH REPUBLIC
}

$\mathrm{T}$ The methodology for the results of research organizations evaluation and the results of completed programs evaluation (valid for the years 2013 to 2015).

\section{What Is The Methodology And Who Evaluates}

The first attempt to develop a methodology for the publication outputs evaluation was established in 2011, but it was insufficient. In 2013, the Research Development and Innovation Council decided to develop a new methodology in which the rules of evaluation were more specified and the methodology was developed in detail.

The evaluation of these eligible publication outputs for the Register of Information on Results ("RIV" in Czech) is undertaken by the Research Development and Innovation Council in stages (see below).

\section{Pillar I and Pillar II}

Pillar I means specialization rating which is done by a software. Within this pillar there is also the so-called Sub-pillar I, meaning panel evaluation, in which the publication outputs are distributed to panel guarantors specialized in the given field, but always from a different institution then the author's one. This is a real and actual evaluation of the outputs (books, chapters, articles).

Pillar II means quality assessment. Faculty offers a number of excellent publication outputs for a given period (books, articles, chapters) and these outputs are judged by an international panel.

\section{Publications Identification (Definition of Types) and Their Division}

All publication outputs must be reviewed (peer reviewed). Publication outputs are further subdivided:

$\mathrm{B}^{1}$ Monograph:

- Reviewed (offsite author's institution).

- Original research.

- At least 50 pages of printed text itself.

- References.

- List of references.

- Footnotes.

- Author's affiliation.

- Abstract - Summary.

- Footnotes.

- Index.

- ISBN.

- Professional / reputable publishing house with editorial board. 
J Article in a periodical journal:

- Expert research article.

- Quotes.

- References.

- Footnotes.

- Reviewed.

- ISSN.

Articles are subdivided into the following categories and on this basis points are awarded. If the journal fails criteria listed below, the author does not receive any points even if the article was published in prestigious international journal:

- Jimp - journal indexed in Web of Knowledge database $^{2}$ (Impact Factor) as Article, Review, Letter or Proceedings Paper.

- Jsc - journal indexed in Scopus database ${ }^{3}$ as Article, Review, Letter or (since 2013) Proceedings Paper.

- Jneimp - journal indexed in ERIH database ${ }^{4}$.

- Jrec - journal included in the list of reviewed non-impact journals, compiled by the Research Development and Innovation Council.

C Chapter in the monograph:

- Must comply with the definitions for the outputs of type B.

- Clear identification of authors of each chapter.

D Article in proceedings:

- Original research.

- Usual structure of scientific work.

- ISBN or ISSN (or both).

- Reviewed.

Articles in proceedings are subdivided into the following categories and on this basis points are awarded. If the proceedings fails criteria listed below, the author does not receive any points even in the case of prestigious international proceedings:

- Proceedings is indexed in Scopus database as Book Series or Conference Proceedings.

- Proceedings is indexed in the Conference Proceedings Citation - Web of Knowledge database.

- Special issue of a journal devoted to the conference contributions, but must be indexed in the above mentioned databases.

\section{Points and Their Allocation}

Points for the publication outputs are allocated as follows:

AG - Jurisprudence

SHVa - for a group of disciplines including Jurisprudence

\begin{tabular}{|l|c|}
\hline $\begin{array}{l}\text { Jimp - journal indexed in Web } \\
\text { of Knowlwdge database (Impact } \\
\text { Factor) }\end{array}$ & $10-305$ points \\
\hline $\begin{array}{l}\text { Jsc - journal indexed in Scopus } \\
\text { database }\end{array}$ & $10-305$ points \\
\hline $\begin{array}{l}\text { Jneimp - journal indexed in } \\
\text { ERIH database }\end{array}$ & $10-30$ points \\
\hline $\begin{array}{l}\text { Jrec - journal included in the list } \\
\text { of reviewed non-impact journals }\end{array}$ & $8-60$ points \\
\hline D Article in proceedings & $\begin{array}{c}\text { calculating the number } \\
\text { of pages throughout } \\
\text { the book to the overall } \\
\text { proportion of pages of } \\
\text { a chapter }\end{array}$ \\
\hline C Chapter in the monograph
\end{tabular}

\section{Negative Points}

Negative points are allocated to the publication outputs which are clearly recognized as outputs inadequate with the Methodology. The negative points are increased against the positive points: e.g. for a well reported monograph the author gets 40 points, but for a book which does not meet the Methodology (e.g. a textbook) author can earn up to minus 60 points. The price of one positive point is e.g. CZK 2500, on the other hand the price of one negative point is CZK 3500.

Other examples of negative points are e.g. textbooks recognized as an expert monograph, published case law with one or two sentences recognized as an article in the journal, etc.

\section{Disadvantages of the Methodology}

Quantity over quality outweighs in this assessment. A large number of points for the faculty equals more money for institutional support.

Academic community is forced before publishing to ascertain whether the journal is scored and how, if it is not 
a predatory publisher. For books it is necessary to choose a clear identification; e.g. if it is the second edition, it must be extended and/or revised, it is necessary to choose an appropriate publishing house, there must not be any notice that it could be used as a textbook, etc.

\section{Picture 1. Comparison of public universities in accor- dance with RIV points in 2012}

Kde jsme se dostali - Metodika

- Porovnání VVŠ podle bodů v RIV, 2012

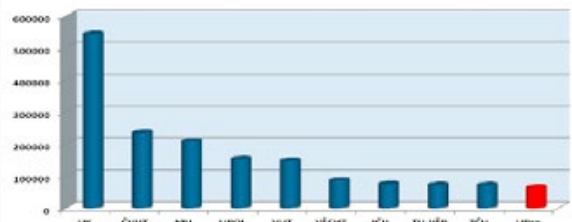

- provadí se korekce bodû, která se odviji od toho, co vyprodukovaly jiné vš,

- prûběžně se zvyšuje počet časopisû registrovaných ve Web of Science a Scopusu, což zvyšuje počet přidělených bodú, aniž by musela produkce článkŭ dané క̌ koly reálně rûst

Source: J. Moravcová, Hodnocení financování VaV v ČR: kde jsem a kam jdeme. Seminář ČVUT, 17.9.2014.

Talking about panel evaluation, we also see the problem that it is an anonymous evaluation only from one side: the evaluator is unknown, but the evaluated is known. The members award $1-3$ points, negative points and zero points (technical zero) for publication outputs professionally fine, but technically not meeting the requirements (missing index, footnotes in the book, etc.).

\section{Conclusions}

At the faculties there must be a referent for the issues dealing with points for publication outputs. They must not only understand the issues of $\mathrm{R} \& \mathrm{D}$, but also know how to fill a record for transfer to the RIV. They must be at least basically oriented in editing, bibliography, citation, and electronic information activities, etc.

Academics must be able to fill out the forms for transmission to the RIV, as they are responsible for records as authors. Unfortunately, the faculty management takes into account the number of points as a benchmark for evaluation of the authors at faculties.

The methodology gives this clear message: no scientific result, no institutional support. It also points out that it does not support multi-disciplinary teams.

Do we need a new methodology in the Czech Republic? Obviously yes. On 1 February 2012 a project to develop a proposal for a new system of evaluation and research funding was launched. The project focuses on International Audit of Research, Development and Innovation in the Czech Republic. A team of international experts worked on this audit till 31 October 2015. They published various analyses, reports and proposals for changes in the rankings. This team also pointed to the global trends in the evaluation. The most important was that the humanities in this respect are very underrated and there is no equal opportunity compared to technical or medical sciences.

Currently, on these recommendations, a new methodology, which should be applied from 2018, is being created. But (as usually) nothing is certain.

\section{BIBLIOGRAPHY}

1. Individuální projekty národní pro oblast terciálníého vzdělávání, výzkumu, vývoje a inovací. Available at: http:// metodika.reformy-msmt.cz/ [13.6. 2016].

2. Metodika hodnocení ve výzkumu a vývoji a zásady financování, Prah: MŠMT, 2015.

3. Metodika hodnocení výsledků výzkumných organizací a hodnocení výsledků ukončených programů (platná pro léta 2013 - 2015). Praha: Úrad vlády ČR, č.j. 1417/2013RVV, schváleno usnesením vlády ze dne 19.6.2013 č. 475.

4. Moravcová J., Hodnocení a financování VaV v ČR: kde jsme a kam jdeme. [Semináŕ]. Praha: ČVUT, 17.9.2014. Available at: https://researchapp.vscht.cz/uploads/attachment/519/ Metodika_Hodnoceni_Moravcov_20140917.pdf.

\section{RIV identification.}

http://apps.webofknowledge.com/.

https://www.scopus.com/search/form.uri?zone=TopNavBarఓorigin=resultslist.

https://dbh.nsd.uib.no/publiseringskanaler/erihplus/. 